\title{
Warfarin Re-initiation Gone Awry: A Case of Inadvertent Overdose Mandating Critical INR Management
}

\author{
Tammy J Bungard and Angela Gee
}

\section{NTRODUCTION}

W arfarin is a commonly used anticoagulant for the primary or secondary prevention of thrombotic events. ${ }^{1}$ Tremendous inter-individual variability in warfarin dosing is apparent, necessitating frequent monitoring via the international normalized ratio (INR). The most feared complication of warfarin therapy is major bleeding, and the risk of this problem increases when the INR exceeds $4.0 .^{2}$ Critical INR values (defined in the Edmonton region of Alberta Health Services as an INR > 5.0; the definition may vary by jurisdiction) are reported urgently to clinicians to enable prompt patient management. For ambulatory patients who are not bleeding, strategies to manage critical INRs include withholding warfarin therapy, with the option of administering oral vitamin $\mathrm{K}_{1}$, but guidelines vary and have changed over time (Table 1). 1,3,4

It is common for patients who are taking warfarin to have their therapy interrupted, for example, when they undergo invasive procedures. For patients at higher risk of thrombosis, low-molecular-weight heparin (LMWH) is commonly prescribed during both the washout period for warfarin (before the procedure) and the build-up period for warfarin (after the procedure). ${ }^{5}$ The duration of postprocedure LMWH depends on the time it takes for the patient's INR to reach a therapeutic level. Clinicians typically restart warfarin at the patient's prior maintenance dose, ${ }^{6,7}$ although in a previous study, we found that it took a median of 20.5 days at the prior maintenance dose to reach a therapeutic $\mathrm{INR}^{8}$; prolonged LMWH therapy is needed during this time.

Reported here is a case of warfarin re-initiation, in which the clinic's usual strategy, based on prior maintenance dosing, resulted in inadvertent warfarin overdose requiring management of a critical INR. For both of these aspects of warfarin management (re-initiation of warfarin and management of critical INR), the literature is reviewed and applied to this case, with emphasis on practical management issues.

\section{CASE REPORT}

A 25-year-old woman who was referred to the Anticoagulation Management Service at the University of Alberta Hospital in November 2008 had been taking warfarin (INR range 2.0-3.0) since having a saddle pulmonary embolism in July 2007.* Her previous medical history included antithrombin III deficiency, protein $\mathrm{C}$ deficiency, factor $\mathrm{V}$ Leiden mutation, and a family history of thrombophilia. She was not taking any other medications.

Under the care of the Anticoagulation Management Service, her INR was maintained within the therapeutic range with a total weekly dose of warfarin 86 to $91 \mathrm{mg}$. She was adherent with warfarin therapy and reported missing 1 or 2 doses per year. She indicated a desire to become pregnant, with plans to try to conceive in early 2012. In collaboration with the Obstetric Medicine Clinic, the clinic instructed her to continue taking warfarin while attempting to become pregnant and to perform pregnancy tests every 1 to 2 weeks. In May 2012, she reported a positive result on a pregnancy test, and it was determined that she was at 4 weeks' gestation. She was instructed to discontinue the warfarin, and enoxaparin $80 \mathrm{mg}$ subcutaneously every $12 \mathrm{~h}$ was prescribed (serum creatinine $61 \mu \mathrm{mol} / \mathrm{L}$ in October 2011, weight $78 \mathrm{~kg}$ in May 2012). Throughout her pregnancy, the LMWH therapy was managed by the Obstetric Medicine Clinic. The patient gave birth on January 17, 2013, and the Anticoagulation Management Service became involved in her care again, for re-initiation of warfarin on February 1 (Figure 1). At that time, she was continuing to self-administer enoxaparin $80 \mathrm{mg}$ subcutaneously every $12 \mathrm{~h}$ (weight $77 \mathrm{~kg}$ in February 2013).

\footnotetext{
*The patient provided consent for publication of this case report.
} 
This single copy is for your personal, non-commercial use only.

For permission to reprint multiple copies or to order presentation-ready copies for distribution, contact CJHP at cjhpedit@cshp.ca

Table 1. Recommendations for Managing Critical International Normalized Ratio (INR)*

\begin{tabular}{|c|c|c|}
\hline Source & Lower Critical Result & Higher Critical Result \\
\hline$\overline{\mathrm{ACCP}(2008)^{1}}$ & $\begin{array}{l}\text { "For patients with an INR } \geq 5.0 \text { but }<9.0 \\
\text { and no significant bleeding, we recommend } \\
\text { omitting the next } 1 \text { or } 2 \text { doses, monitoring } \\
\text { more frequently, and resuming therapy at } \\
\text { an appropriately adjusted dose when the } \\
\text { INR is at a therapeutic level (Grade } 1 C \text { ). } \\
\text { Alternatively, we suggest omitting a dose } \\
\text { and administering vitamin } \mathrm{K}_{1}(1-2.5 \mathrm{mg} \text { ) } \\
\text { orally, particularly if the patient is at } \\
\text { increased risk of bleeding (Grade } 2 \mathrm{~A}) . "\end{array}$ & $\begin{array}{l}\text { "For patients with an INR } \geq 9.0 \text { and no } \\
\text { significant bleeding, we recommend } \\
\text { holding warfarin and administering a } \\
\text { higher dose of vitamin } \mathrm{K}_{1}(2.5-5 \mathrm{mg}) \\
\text { orally, with the expectation that the INR } \\
\text { will be reduced substantially in } 24-48 \mathrm{~h} \\
\text { (Grade } 1 \mathrm{~B}) . \text {." }\end{array}$ \\
\hline$\overline{\operatorname{ACCP}(2012)^{3}}$ & $\begin{array}{l}\text { "For patients taking VKAs with INRs } \\
\text { between } 4.5 \text { and } 10.0 \text { and with no } \\
\text { evidence of bleeding, suggest against } \\
\left.\text { routine use of vitamin } \mathrm{K}_{1} \text { (Grade } 2 \mathrm{~B}\right) . "\end{array}$ & $\begin{array}{l}\text { "For patients taking VKAs with INRs > } 10.0 \\
\text { and no evidence of bleeding suggest that } \\
\text { oral vitamin } \mathrm{K}_{1} \text { be administered (Grade } 2 \mathrm{C} \text { )." }\end{array}$ \\
\hline $\begin{array}{l}\text { ESC/EACTS } \\
(2012)^{4}\end{array}$ & $\begin{array}{l}\text { "... to stop oral anticoagulation and to } \\
\text { allow the INR to fall gradually or to give } \\
\text { oral vitamin } K_{1} \text { in increments of } 1 \text { or } 2 \text { mg." }\end{array}$ & $\begin{array}{l}\text { "If the INR is }>10 \text {, higher doses of oral } \\
\text { vitamin } K_{1}(5 \mathrm{mg}) \text { should be considered." }\end{array}$ \\
\hline \multicolumn{3}{|c|}{$\begin{array}{l}\text { ACCP = American College of Chest Physicians, ESC/ EACTS = European Society of Cardiology/ } \\
\text { European Association for Cardio-Thoracic Surgery, VKA = vitamin K antagonist. } \\
\text { *Definitions of grades appearing in this table: Grade } 1 \mathrm{~B}=\text { strong recommendation, moderate quality } \\
\text { evidence; Grade } 1 \mathrm{C}=\text { strong recommendation, low or very low quality evidence; Grade } 2 \mathrm{~A}=\text { weak } \\
\text { recommendation, high quality evidence; Grade } 2 \mathrm{~B}=\text { weak recommendation, moderate quality } \\
\text { evidence; Grade } 2 \mathrm{C}=\text { weak recommendation, low quality evidence. }\end{array}$} \\
\hline
\end{tabular}

The patient had some warfarin left over from before her pregnancy and was also given new prescriptions for warfarin 1-mg, 5-mg, and 10-mg tablets, which she planned to fill as needed. Given that her prior warfarin requirement had been $12-$ $13 \mathrm{mg}$ daily, she was instructed to take $18 \mathrm{mg}$ daily for 3 days and then $12 \mathrm{mg}$ on the fourth day and to have standard laboratory venipuncture for an INR and complete blood count on the fifth day (i.e., February 5). The enoxaparin therapy was to be continued.
On the afternoon of February 5, her INR was reported to be 9.9, and her complete blood count was unchanged from previous results. The clinical assessment indicated no bleeding or bruising and did not reveal any reason (changes in health, medications, or lifestyle) for this critical INR value. Upon review of warfarin dosing, it was determined that she was taking the drug in the morning and that she had taken warfarin $18 \mathrm{mg}$ on February 2 and 3 and warfarin $12 \mathrm{mg}$ on February 4 and 5. The patient was instructed to discontinue enoxaparin and withhold

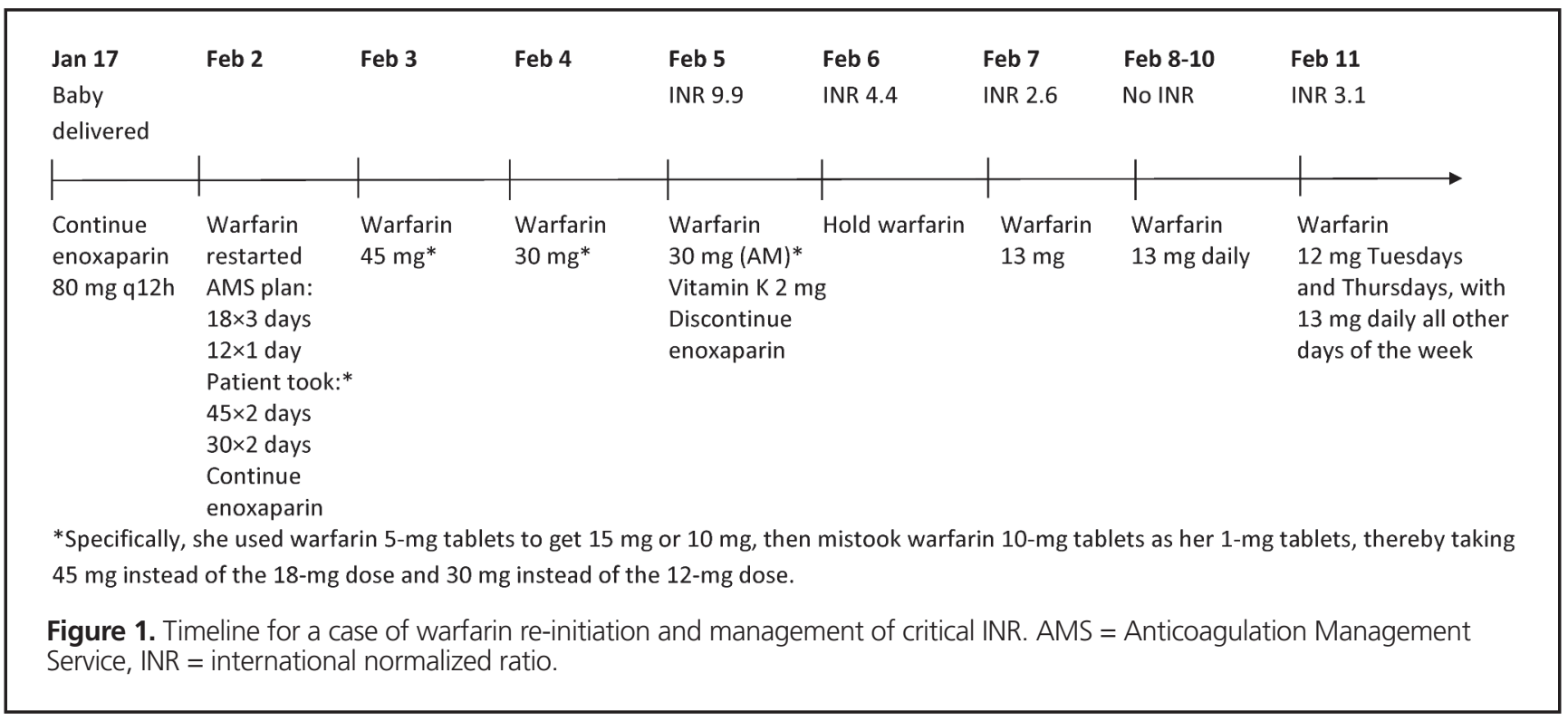


warfarin. Oral vitamin $\mathrm{K}_{1} 2 \mathrm{mg}$ was prescribed, and the patient was counselled about the increased risk of bleeding and general precautions to be taken with a critical INR. She was instructed to have blood drawn for INR on February 6 (i.e., the next day) and to not take any warfarin that morning.

Early on February 6, the patient called back to report that on February 2 through 5, she had mistaken her warfarin 10-mg tablets for warfarin 1-mg tablets; as a result, she had inadvertently taken warfarin $45 \mathrm{mg}$ on February 2 and 3 and warfarin $30 \mathrm{mg}$ on February 4 and 5. Later that day (February 6), her INR was 4.4, and she continued to deny any notable findings. Withholding of warfarin was continued, and on February 7, her INR was 2.6. Warfarin $13 \mathrm{mg}$ daily was then prescribed (to start on February 7), and INR measured on February 11 was 3.1. Ultimately, her warfarin requirements to maintain her target INR (84-90 mg weekly) were similar to prepregnancy dosing.

\section{DISCUSSION}

This case featured 2 distinct aspects of warfarin management: re-initiation of warfarin in the setting of known maintenance dosing and management of critical INRs in an ambulatory, nonbleeding patient. Warfarin re-initiation with known prior maintenance dosing differs from de novo initiation of warfarin therapy, as the prior warfarin requirements can be used to guide future dosing decisions, the most conservative strategy being re-initiation at the prior maintenance doses. Guidelines for management of critical INRs have been published by North American $^{1,3}$ and European ${ }^{4}$ organizations, but they differ from one another and have changed over time (Table 1). This variability highlights the need to individualize management strategies, particularly in unique clinical cases.

\section{Re-initiation of Warfarin in the Setting of Known Maintenance Doses}

Restarting warfarin in the setting of known prior maintenance doses most commonly occurs when periprocedural management is required. Supporting data take the form of expert opinion based on observational studies, with randomized trials currently underway. ${ }^{5}$ Most authorities suggest restarting warfarin at the usual maintenance dose the evening of the day on which the procedure or surgery has taken place. ${ }^{1,6,9,10}$ In our experience, however, resuming warfarin at the patient's usual maintenance dose following an elective procedure that did not require hospital admission resulted in a long delay (median 20.5 days) to achieve an INR of 2.0 or above. ${ }^{8}$ During this prolonged interval, many patients must continue taking LMWH. These findings were supported by another anticoagulation management service, which reported that the duration of LMWH administration was significantly longer (mean \pm standard deviation $12.0 \pm 8.2$ days) than that reported in clinical trials. ${ }^{11}$ Patients' frustration with this prolonged delay to reach an INR of 2.0 is attributable to the ongoing cost of the LMWH and the need to continue selfadministration by injection.

The study institution's Anticoagulation Management Service typically restarts warfarin at 1.5 times the known maintenance dose for the first 2 to 3 days, followed by step-down to the usual maintenance dose for 1 to 2 days, with subsequent dosing guided by INR assessment. ${ }^{8}$ As such, it takes a median of 5 days to achieve a therapeutic INR in the clinic's ambulatory population. This dosing strategy takes into consideration the delayed effect of warfarin and provides for 1 or 2 maintenance doses before the INR is measured to allow more time to see the effects of the initial reloading doses. Using a slightly different approach, others have resumed warfarin at twice the usual warfarin dose the evening of the procedure and reported the mean time to achieve INR above 2.0 as 4.6 days (range 2-10). ${ }^{12}$

As in the case reported here, the Anticoagulation Management Service at the study institution administers warfarin loading doses in conjunction with therapeutic LMWH administration, given the theoretical potential to induce a hypercoagulable state with depletion of proteins $C$ and $S$. In the current case, the intent was to have the patient self-administer about 1.5 times the maintenance dose for 3 days, followed by her regular dose on day 4 and INR measurement on day 5. The patient typically took her warfarin in the morning, so she started her warfarin the morning after the consultation (i.e., February 2) and intended to take warfarin $18 \mathrm{mg}$ for the first 2 days, followed by warfarin $12 \mathrm{mg}$ daily. Given her morning warfarin intake, she had already taken her warfarin dose on February 5, the day when the critical INR result was obtained. She later realized that confusion with her tablets had resulted in an overt overdose. Specifically, on the first and second days (February 2 and 3), she used warfarin 5-mg tablets to get $15 \mathrm{mg}$ and intended to take three $1-\mathrm{mg}$ tablets for the total dose of $18 \mathrm{mg}$; similarly, on the third and fourth days (February 4 and 5), she used warfarin 5-mg tablets to get $10 \mathrm{mg}$ and intended to take two 1-mg tablets for the total dose of 12 mg. However, for all of these doses, she mistook warfarin 10-mg tablets for 1-mg tablets, so her total doses were $45 \mathrm{mg}$ on February 2 and 3 and $30 \mathrm{mg}$ on February 4 and 5.

\section{Warfarin Overdose}

Cases of warfarin overdose (involving about $250 \mathrm{mg}$ ) were reported as early as 1978 , and those early cases were treated with multiple days of very high doses of vitamin $\mathrm{K}_{1}$ (repeated daily dosing of $10-40 \mathrm{mg}),{ }^{13}$ on the hypothesis that the turnover rate of vitamin $\mathrm{K}_{1}$ was much faster than that of warfarin. ${ }^{14}$ In 2003, Isbister and others ${ }^{15}$ published 3 cases of intentional warfarin overdose (120-150 mg). For patients at increased thromboembolic risk, where subtherapeutic warfarin therapy would necessitate heparin (as in the current case), these authors suggested to assess the INR every $6 \mathrm{~h}$, with titration of IV vitamin $\mathrm{K}_{1} 0.5-2 \mathrm{mg}$ as 
long as the INR remains above $5.0 .^{15}$ The current case differed from these cases, however, in that the overdose involved much less warfarin, likely because the overdose was unintentional. The patient notified the Anticoagulation Management Service of the tablet mix-up the day after the critical INR was obtained, which meant that pharmacy staff had to initially manage this result as a critical INR without a clearly defined cause.

\section{Management of Critical INR}

Management of critical INRs in an ambulatory care setting encompasses making a determination that outpatient management can continue (by ruling out bleeding, bruising, or any other concerning issue that requires further assessment or referral to an emergency department), assessing the individual patient's risk of bleeding versus clotting (to determine the aggressiveness of INR management in the particular case), and assessing factors that might be causing or contributing to the critical INR result. In this case, the patient reported no bleeding or bruising, and no reason could be identified as contributing to this critical INR on the day it was reported. Her past history indicated that she was at high thromboembolic risk, given her extensive pulmonary embolus and documented hypercoagulable states. Her bleeding risk was low, with no identified risk factors for bleeding, which lent support to the attempt to prevent overcorrection of her warfarin therapy. The 2 strategies considered were withholding of warfarin (although she had already taken her warfarin on the day the critical INR result was obtained) and oral administration of vitamin $\mathrm{K}_{1}$.

\section{Withholding Warfarin}

In the setting of critical INR management, all available data support holding warfarin therapy for 1 or 2 days, followed by INR reassessment. ${ }^{3,4} \mathrm{~A}$ study assessing the rate of INR decay among patients with a mean entry INR of 8.1 (range 6.1-29.8) showed that after warfarin was held, $33 \%$ of the patients had an INR below 4 within 24 h, 55\% within 48 h, $73 \%$ within 72 h, and nearly $90 \%$ within 96 h. ${ }^{16}$ The patients with entry INRs above $10(n=13)$ took longer to reach an INR below 4 (mean 3.6 days) than those with entry INRs between 6.1 and 10.0 ( $n=92$; mean 2.9 days). This pattern was confirmed by another study, in which warfarin was withheld for patients with an entry INR above 10.0; for nearly half of the patients ( $n=7$ [47\%]), the INR remained above 5.0 on day $3 .{ }^{17}$

In the case reported here, on the day that the patient's critical INR was reported, no reason could be identified for the critical INR, which left pharmacy staff to contemplate either laboratory error or an alteration in previous warfarin requirements as the cause of the INR value. Although laboratory error does occur, it is rare, and it was decided to not repeat INR testing the same day and to manage the critical INR accordingly. Even if the patient had taken the warfarin as prescribed (i.e., 18- and 12-mg doses instead of the later-discovered 45- and 30-mg doses), evidence ${ }^{16,17}$ indicates that simply holding her warfarin dose the next day would have left the INR at a critical level (INR > 5.0) for at least another 48 to $72 \mathrm{~h}$, exposing the patient to unnecessary risk of bleeding. As such, the option of oral vitamin $\mathrm{K}_{1}$ therapy was pursued.

\section{Administration of Oral Vitamin $K_{1}$}

Numerous case series ${ }^{17-24}$ and a few small randomized trials ${ }^{25-28}$ support the use of small doses of oral vitamin $K_{1}$ (ranging from 1 to $5 \mathrm{mg}$ ) to reverse asymptomatic over-anticoagulation $($ INR $>4.5)$ in a reliable and predictable manner (Table 2). The amount given is guided by the specific level of the INR. Data support oral vitamin $\mathrm{K}_{1} 1-2.5 \mathrm{mg}$ for those with INRs between 4.5 and $10,{ }^{20,21,24,25-28}$ whereas doses of 2-5 mg are supported for INRs exceeding 8. ${ }^{18,19,22-24,27}$

Although data support oral administration of vitamin $\mathrm{K}_{1}$ to rapidly reverse supratherapeutic INRs to therapeutic INRs, it is still unknown whether this strategy reduces the likelihood of bleeding. ${ }^{22,25}$ In a randomized, blinded trial evaluating 716 nonbleeding patients with INRs between 4.5 and 10 who received either oral vitamin $\mathrm{K}_{1} 1.25 \mathrm{mg}$ or placebo, there was no significant difference in any aspect of bleeding at 90 days, despite a significantly greater decline in INRs in the vitamin $\mathrm{K}_{1}$ group (from 5.95 to 3.17 in the vitamin $\mathrm{K}_{1}$ group and from 5.75 to 4.40 in the placebo group; $p<0.001) .{ }^{25}$ In a parallel cohort study of patients with INRs above 10, designed to assess whether low-dose $\left(2.5 \mathrm{mg}\right.$ ) oral vitamin $\mathrm{K}_{1}$ reduced bleeding events, the overall bleeding rate was $22 \%$, with $3.7 \%$ of patients having major bleeding within 90 days of the index INR. ${ }^{22}$ This study lacked a control group, ${ }^{22}$ and the placebo-controlled, randomized trial of patients with INRs between 4.5 and 10 described above ${ }^{25}$ was underpowered to detect differences in major bleeding. Despite attempts to assess patient outcomes (i.e., bleeding) as opposed to surrogate measures (INR results), this question remains unanswered. In general, there is less merit to administering oral vitamin $K_{1}$ if the INR is between 5.4 and $7^{25,28}$; however, the more prolonged interval to decay for those with INR exceeding 8 suggests that there may be some benefit in doing so for these patients. ${ }^{17-19,23,24}$

In the case reported here, it was decided to administer oral vitamin $K_{1} 2 \mathrm{mg}$ and to reassess the INR the next day. This approach was based on the patient's young age (and anticipated quicker rate of warfarin decay) and the goal of sustaining an INR of at least 2, given her thromboembolic risk. The rationale for administering vitamin $\mathrm{K}_{1}$ was 2-fold: first, the patient had already taken her warfarin dose that morning and it was anticipated that she would not experience any reduction in INR until she had missed her next dose the following morning; second, no reason for the critical INR could be discerned. Use of a 2-mg 
Table 2. Effect of Oral Vitamin $\mathrm{K}_{1}$ on Critical INR

\begin{tabular}{|c|c|c|c|c|}
\hline Source and INR Eligibility & No.* & INR at Entry & $\begin{array}{l}\text { Vitamin } \mathrm{K}_{1} \\
\text { Dose (mg) }\end{array}$ & Outcome \\
\hline Crowther et al. $(2000)^{26}$ & 45 & $\begin{array}{l}\text { Mean } \pm \text { SD } 5.4 \pm 1.0 \\
\text { (range 4.5-9.8) }\end{array}$ & 1 & $\begin{array}{l}\text { INR next day: mean } \pm \text { SD: } 2.6 \pm 0.9 \\
<1.8 \text { for } 16 \%\end{array}$ \\
\hline INR 4.5-10 & & & & $\begin{array}{l}1.8-3.2 \text { for } 56 \% \\
>3.2 \text { for } 28 \%\end{array}$ \\
\hline $\begin{array}{l}\text { Crowther et al. }(1998)^{21} \\
\text { INR 4.5-10 }\end{array}$ & 62 & $\begin{array}{l}\text { Mean } 5.7(95 \% \mathrm{Cl} \\
5.48-6.09) \text {, range } 4.5-9.5\end{array}$ & 1 & $\begin{array}{l}\text { INR at } 16 \mathrm{~h}: 2.86 \\
(95 \% \mathrm{Cl} 2.50-3.23)\end{array}$ \\
\hline Crowther et al. $(2002)^{20}$ & 26 & Mean \pm SD $5.8 \pm 1.2$ & 1 & $\begin{array}{l}\text { INR next day: mean } \pm \text { SD: } 2.9 \pm 0.8 \\
<1.8 \text { for } 12 \%\end{array}$ \\
\hline INR 4.5-10 & & & & $\begin{array}{l}1.8-3.2 \text { for } 57 \% \\
>3.2 \text { for } 31 \%\end{array}$ \\
\hline $\begin{array}{l}\text { Crowther et al. }(2009)^{25} \\
\text { INR 4.5-10 }\end{array}$ & 347 & $\begin{array}{l}\text { Mean } 5.95 \\
(95 \% \text { Cl 5.83-6.07) }\end{array}$ & 1.25 & $\begin{array}{l}\text { INR next day: } \\
\text { mean } 3.17(95 \% \mathrm{Cl} 3.06-3.28)\end{array}$ \\
\hline Patel et al. $(2000)^{28}$ & 15 & Mean 7.2 (range 6.0-9.2) & 2.5 & $\begin{array}{l}\text { Mean time } \pm \text { SD to INR }<4 \text { : } \\
1.4 \pm 0.5 \text { days }\end{array}$ \\
\hline INR 6.0-10 & & & & $\begin{array}{l}\text { Mean INR decrease } \pm \text { SD: } \\
4.85 \pm 1.4 \text { units }\end{array}$ \\
\hline Weibert et al. (1997) ${ }^{24}$ & 81 & $>5.0(n=10$ with INR > 10) & 2.5 & $\begin{array}{l}\text { INR at } 24 \mathrm{~h}: \\
<2.0 \text { for } 17 \%\end{array}$ \\
\hline INR $>5$ & & & & $\begin{array}{l}2-5 \text { for } 72 \% \\
>5 \text { for } 10 \%(4 \text { patients had } \\
\text { entry INR }>10)\end{array}$ \\
\hline \multirow[t]{2}{*}{ Lubetsky et al. (2003) } & 47 & $\begin{array}{l}\text { INR category 6-10: } \\
\text { mean } \pm \text { SD } 7.7 \pm 1.1 \\
(\text { range 6.1-9.6) }\end{array}$ & 2.5 & $\begin{array}{l}\text { INR next day: } \\
\text { mean } \pm \text { SD: } 2.9 \pm 0.8\end{array}$ \\
\hline & 9 & $\begin{array}{l}\text { INR category > 10: } \\
\text { mean } \pm \text { SD } 13.0 \pm 1.7 \\
\text { (range 10.4-15.1) }\end{array}$ & 5 & $\begin{array}{l}\text { INR at } 48 \mathrm{~h}: \\
\text { mean } \pm \text { SD: } 2.8 \pm 1.2\end{array}$ \\
\hline $\begin{array}{l}\text { Denas et al. }(2009)^{23} \\
\text { INR }>10\end{array}$ & 104 & $\begin{array}{l}\text { Median 11.3 } \\
\text { (IQR 10.6-13.1) }\end{array}$ & 3 & $\begin{array}{l}\text { INR next day: } \\
\text { median 2.9 (IQR 2.2-3.7) }\end{array}$ \\
\hline $\begin{array}{l}\text { Crowther et al. }(2010)^{22} \\
\text { INR }>10\end{array}$ & 107 & $\begin{array}{l}\text { Mean 12.6 } \\
\text { (range 10-26.6)† }\end{array}$ & 2.5 & $\begin{array}{l}\text { INR in } 24 \text { h: } \\
\text { mean } 4.7 \text { (range 1.3-20.2) }\end{array}$ \\
\hline \multirow[t]{3}{*}{ Baker et al. $(2006)^{18}$} & 166 & INR category 8.0-11.9 & 2.5 & $\begin{array}{l}\text { INR next day: median } 3.5 \\
<2 \text { for } 8 \% \\
2-4.9 \text { for } 79 \% \\
>4.9 \text { for } 13 \%\end{array}$ \\
\hline & 36 & INR category 12.0-20.0 & 5 & $\begin{array}{l}\text { INR next day: median } 3.0 \\
<2 \text { for } 17 \% \\
2-4.9 \text { for } 52 \% \\
>4.9 \text { for } 31 \%\end{array}$ \\
\hline & 21 & INR category $>20$ & 5 & $\begin{array}{l}\text { INR next day: median } 2.9 \\
<2 \text { for } 29 \% \\
2-4.9 \text { for } 42 \% \\
>4.9 \text { for } 29 \%\end{array}$ \\
\hline \multirow[t]{3}{*}{ Chirputkar et al. $(2006)^{19}$} & 59 & INR category 8-8.9 & 2 & $\begin{array}{l}\text { INR next day: } \\
<2 \text { for } 21 \% \\
2-4 \text { for } 63 \% \\
>4 \text { for } 16 \%\end{array}$ \\
\hline & 41 & INR category 9-10.9 & 2 & $\begin{array}{l}\text { INR next day: } \\
<2 \text { for } 20 \% \\
2-4 \text { for } 46 \% \\
>4 \text { for } 34 \%\end{array}$ \\
\hline & 26 & INR category $>11$ & 2 & $\begin{array}{l}\text { INR next day: } \\
<2 \text { for } 7 \% \\
2-4 \text { for } 70 \% \\
>4 \text { for } 22 \%\end{array}$ \\
\hline
\end{tabular}

$\mathrm{CI}=$ confidence interval, INR = international normalized ratio, IQR = interquartile range, $\mathrm{SD}=$ standard deviation.

*Number of patients receiving vitamin $\mathrm{K}_{1}$ with follow-up.

tDoes not include 10 cases in which INR was above the limit of measurement. 
dose was supported by the findings of a literature review ${ }^{18,19,22,23}$ and the belief that this was a conservative amount of vitamin $K_{1}$, given the patient's high thromboembolic risk. The patient's INR was assessed the next day (result: 4.4), following which staff learned of the inadvertent overdose. Warfarin was again withheld, INR the next day was 2.6, and a maintenance dose of warfarin $13 \mathrm{mg}$ daily was then instituted. When feasible, practice in the Anticoagulation Management Service is to routinely assess the INR the day after oral administration of vitamin $\mathrm{K}_{1}$ to assess the patient's status and to ensure that warfarin is restarted in a timely manner to prevent subsequent subtherapeutic anticoagulation.

Previous studies assessing the use of oral vitamin $\mathrm{K}_{1}$ have recommended restarting warfarin once the INR returns to the desired therapeutic range (often using an expanded range of \pm 0.2 INR units) $)^{21,25}$ or once the INR falls below a critical level, either less than $5^{18,24}$ or less than $4 .^{28}$ Delaying the re-initiation of warfarin places the patient at risk of subtherapeutic anticoagulation. The front-line clinician must appreciate that after 16-24 h, the effect of oral vitamin $K_{1}$ will be evident (when administered in small doses); however, the full impact of withholding warfarin will continue. As such, clinical practice at the study institution is to restart warfarin when the INR approaches or drops below 4 for most patients.

The root cause of the critical INR in this case was a warfarin tablet mix-up, which occurred despite the patient being reliable, well educated, and adept at taking different doses of warfarin on different days of the week. Given the variability in daily dosing, it is the clinic's practice, for most patients, not to prescribe a single warfarin tablet strength, but use of a single strength might have prevented the problem that occurred in this case.

\section{CONCLUSION}

This case featured several unique aspects of daily warfarin management, including re-initiation of therapy in the setting of known prior maintenance dosing and management of critical INRs, specifically by withholding warfarin, administering oral vitamin $\mathrm{K}_{1}$, and re-initiating warfarin in a timely fashion afterward. Upon restarting warfarin in the setting of known prior maintenance dosing, use of higher warfarin doses (about 1.5 times the usual maintenance dose) for 2 or 3 days, followed by step-down to the maintenance dose, expedites the achievement of a therapeutic INR. ${ }^{8}$ While it can be concluded that data support the use of oral vitamin $\mathrm{K}_{1}$ to more quickly achieve a therapeutic INR in the setting of critical INR management in nonbleeding ambulatory patients, ${ }^{25-28}$ no outcome data are available to support the contention that oral vitamin $\mathrm{K}_{1}$ reduces bleeding. ${ }^{22,25}$ Data do suggest that it is more compelling to administer oral vitamin $\mathrm{K}_{1}$ to those with higher critical INRs (e.g., INR > 8), given the longer interval for the INR to decay back to the therapeutic range. ${ }^{18,19,22-24,27}$ Ultimately, the use and dose of oral vitamin $\mathrm{K}_{1}$ should be guided by the specific level of the INR, the underlying reason for the critical INR, whether warfarin doses have already been administered on the day of the critical INR, and the individual patient's overall risk of thrombosis and bleeding. Prompt attention should be given to warfarin re-initiation once the INR is no longer critical, in an attempt to avoid subtherapeutic anticoagulation. Finally, patient education and clarity about warfarin dosing are paramount. Although the patient in this case was knowledgeable and familiar with warfarin therapy, an important dosing error still occurred, reinforcing the need to avoid making assumptions.

\section{References}

1. Ansell J, Hirsh J, Hylek E, Jacobson A, Crowther M, Palareti G; American College of Chest Physicians. Pharmacology and management of the vitamin $\mathrm{K}$ antagonists: American College of Chest Physicians evidence-based clinical practice guidelines (8th edition). Chest. 2008;133(6 Suppl):160S-198S

2. Hylek EM, Singer DE. Risk factors for intracranial hemorrhage in outpatients taking warfarin. Ann Intern Med. 1994;120(11):897-902.

3. Holbrook A, Schulman S, Witt DM, Vandvick PO, Fish J, Kovacs M, et al. Evidence-based management of anticoagulation therapy: antithrombotic therapy and prevention of thrombosis, 9th ed: American College of Chest Physicians evidence-based clinical practice guidelines. Chest. 2012;141(2 Suppl):e152S-84S.

4. Joint task force on the management of valvular heart disease of the European Society of Cardiology (ESC) and the European Association for Cardio-Thoracic Surgery (EACTS); Vahanian A, Alfieri O, Andriotti F, Antunes MJ, BarónEsquivias G, Baumgartner H, et al. Guidelines on the management of valvular heart disease (version 2012). Eur Heart J. 2012;33(19):2451-96.

5. Douketis JD, Spyropoulos AC, Spencer FA, Mayr M, Jaffer AK, Eckman $\mathrm{MH}$, et al.; American College of Chest Physicians. Perioperative management of antithrombotic therapy: antithrombotic therapy and prevention of thrombosis, 9th ed: American College of Chest Physicians evidence-based clinical practice guidelines. Chest. 2012;141(2 Suppl):e326S-50S.

6. Douketis JD, Johnson JA, Turpie AG. Low-molecular-weight heparin as bridging anticoagulation during interruption of warfarin: assessment of a standardized periprocedural anticoagulation regimen. Arch Intern Med. 2004;164(12):1319-26.

7. Spyropoulos AC, Turpie AGG, Dunn AS, Spandorfer J, Douketis J, Jacobson $A$, et al.; REGIMEN Investigators. Clinical outcomes with unfractionated heparin or low-molecular-weight heparin as bridging therapy in patients on long-term oral anticoagulants: the REGIMEN registry. J Thromb Haemostasis. 2006;4(6):1246-52.

8. Schultz KT, Bungard TJ. Dosing options for decreasing the time to achieve therapeutic anticoagulation when reinitiating warfarin: a case series. Pharmacotherapy. 2011;31(8):793-805.

9. Kaatz S, Paje D. Update in bridging anticoagulation. J Thromb Thrombolysis. 2011;31(3):259-64.

10. Spyropoulos AC, Douketis JD. How I treat anticoagulated patients undergoing an elective procedure or surgery. Blood. 2012;120(15):2954-62.

11. Deerhake JP, Merz JC, Cooper JV, Eagle KA, Fay WP. The duration of anticoagulation bridging therapy in clinical practice may significantly exceed that observed in clinical trials. J Thromb Thrombolysis. 2007;23(2):107-13.

12. Kovacs MJ, Kearon C, Rodger M, Anderson DR, Turpie AG, Bates SM, et al. Single-arm study of bridging therapy with low-molecular-weight heparin for patients at risk of arterial embolism who require temporary interruption of warfarin. Circulation. 2004;110(12):1658-63.

13. Bjornsson TD, Blaschke TF. Vitamin K1 deposition and therapy of warfarin overdose. Lancet 1978;2(8094):846-7.

14. Shearer MJ, Barkhan P. Vitamin K1 and therapy of massive warfarin overdose. Lancet 1979;1(8110):266-7.

15. Isbister GK, Hackett LP, Whyte IM. Intentional warfarin overdose. Ther Drug Monit. 2003;25(6):715-22.

16. Hylek EM, Chang YC, Skates SJ, Hughes RA, Singer DE. Prospective study of the outcomes of ambulatory patients with excessive warfarin anticoagulation. Arch Intern Med. 2000;160(11):1612-7. 
17. Gunther KE, Conway G, Leibach L, Crowther MA. Low-dose oral vitamin $\mathrm{K}$ is safe and effective for outpatient management of patients with an INR>10. Thromb Res. 2004;113(3-4):205-9.

18. Baker P, Gleghorn A, Tripp T, Paddon K, Eagleton H, Keeling D. Reversal of asymptomatic over-anticoagulation by orally administered vitamin K. $\mathrm{Br}$ J Haematol. 2006;133(3):331-6.

19. Chirputkar SK, Poole JH, McNeil RC, Tansey P, Etherington AM, Morrison $\mathrm{C}$, et al. Reversal of asymptomatic over-anticoagulation with oral vitamin K. Br J Haematol. 2006;135(4):591-2.

20. Crowther MA, Douketis JD, Schnurr T, Steidl L, Mera V, Ultori C, et al. Oral vitamin $\mathrm{K}$ lowers the international normalized ratio more rapidly than subcutaneous vitamin $\mathrm{K}$ in the treatment of warfarin-associated coagulopathy. A randomized, controlled trial. Ann Intern Med. 2002;137(4):251-4.

21. Crowther MA, Donovan D, Harrison L, McGinnis J, Ginsberg J. Low-dose oral vitamin $\mathrm{K}$ reliably reverses over-anticoagulation due to warfarin. Thromb Haemost. 1998;79(6):1116-8.

22. Crowther MA, Garcia D, Ageno W, Wang L, Witt D, Clark NP, et al. Oral vitamin $\mathrm{K}$ effectively treats international normalised ratio (INR) values in excess of 10: results of a prospective cohort study. Thromb Haemost. 2010;104(1):118-21.

23. Denas G, Cucchini U, Iliceto S, Pengo V. An oral vitamin K protocol to reverse over-anticoagulation in patients presenting with an international normalised ratio above 10.0. Thromb Haemost. 2009;101(2):410-1.

24. Weibert RT, Le DT, Kayser SR, Rapaport SI. Correction of excessive anticoagulation with low-dose oral vitamin K1. Ann Intern Med. 1997; 126(12):959-62.

25. Crowther MA, Ageno W, Garcia D, Wang, L, Witt D, Clark NP, et al. Oral vitamin $\mathrm{K}$ versus placebo to correct excessive anticoagulation in patients receiving warfarin: a randomized trial. Ann Intern Med. 2009;150(5): 293-300.

26. Crowther MA, Julian J, McCarty D, Douketis J, Kovacs M, Biagoni L, et al. Treatment of warfarin-associated coagulopathy with oral vitamin K: a randomised controlled trial. Lancet. 2000;356(9241):1551-53.
27. Lubetsky A, Yonath H, Olchovsky D, Loebstein R, Halkin H, Ezra D. Comparison of oral vs intravenous phytonadione (vitamin K1) in patients with excessive anticoagulation: a prospective randomized controlled study. Arch Intern Med. 2003;163(20):2469-73.

28. Patel RJ, Witt DM, Saseen JJ, Tillman DJ, Wilkinson DS. Randomized, placebo-controlled trial of oral phytonadione for excessive anticoagulation. Pharmacotherapy. 2000;20(10):1159-66.

Tammy J Bungard, BSP, PharmD, is Director of the Anticoagulation Management Service, University of Alberta Hospital; and an Associate Professor in the Division of Cardiology, Department of Medicine, University of Alberta; Edmonton, Alberta.

Angela Gee, BScPharm, is a Clinical Pharmacist with the Anticoagulation Management Service, University of Alberta Hospital, Edmonton, Alberta.

Competing interests: Tammy J Bungard has received honoraria from Boehringer-Ingelheim, Bayer and BMS-Pfizer. No competing interests declared by Angela Gee.

Address correspondence to:

Dr Tammy J Bungard

Research Transition Facility

EPICORE Centre

University of Alberta

4000, 8308-114 Street

Edmonton $A B$ T6G 2V2

e-mail: tammy.bungard@ualberta.ca

Acknowledgements: The authors would like to thank Melissa Chung for her assistance in compiling preliminary information for this report. The authors would also like to acknowledge the patient described in this report, who provided explicit consent to publish detailed information from her case.

\title{
CISADL 2014
}

\section{The 2014 Canadian Investigational \& Special Access Drug List is now on sale!}

\author{
Please place your order by completing our online form at \\ www.cshp.ca/productsServices/otherPublications/canadianInvestigational_e.asp
}

The CISADL is a compilation of drugs that are currently not marketed in Canada, and may have Investigational or Special Access status with Health Canada. This list is not endorsed by Health Canada's Special Access Program. For precise information about the regulatory status of a drug, contact the Special Access Program directly. Entries to the list are contributed to by several Drug Information Centers across Canada and by Canadian drug manufacturers. In cases where non-marketed drugs do not appear on the list, foreign references should be consulted. The content of the list includes generic name and strength/concentration, dosage form, pharmacology/therapeutic use, trade and code name, source (manufacturer/distributor), and comments. Available in English only. 